\title{
Environmental drivers of plant assemblages: are there differences between palustrine and lacustrine wetlands? A case study from the northern Apennines (Italy)
}

\author{
Claudia Angiolini ${ }^{1}$, Daniele Viciani ${ }^{2}$, Gianmaria Bonari ${ }^{3,}$, Antonio Zoccola ${ }^{4}$, Alessandro Bottacci ${ }^{5}$, \\ Paola Ciampelli ${ }^{4}$, Vincenzo Gonnelli ${ }^{6}$ and Lorenzo Lastrucci ${ }^{7}$ \\ ${ }^{1}$ Department of Life Sciences, University of Siena, Via P.A. Mattioli 4, 53100 Siena, Italy \\ 2 Department of Biology, University of Florence, Via G. La Pira 4, I-50121 Florence, Italy \\ ${ }^{3}$ Department of Botany and Zoology, Masaryk University, Kotlářská 2, CZ-611 37 Brno, Czech Republic \\ ${ }^{4}$ Reparto Carabinieri Biodiversità Pratovecchio, Via Dante Alighieri 41, Pratovecchio-Stia (AR), Italy \\ ${ }^{5}$ Comando Regione Carabinieri Forestali "Toscana", Ufficio CTO Firenze, Piazza Edison 11, Florence, Italy \\ ${ }^{6}$ Istituto di Istruzione Superiore "Camaiti", Via San Lorenzo 18, 52036 Pieve Santo Stefano Arezzo, Italy \\ ${ }^{7}$ University Museum System, Natural History Museum of the University of Florence, Botany, Via G. La Pira 4, 50121 Florence, Italy
}

Received 15 May 2019 / Accepted 26 June 2019

\begin{abstract}
Mountain wetlands are among the most vulnerable habitats in the Mediterranean basin. Their conservation requires knowledge of plant species assemblages and their environmental drivers. In this study, we investigated what the main environmental factors driving species composition in mountain wetlands are. Differences in environmental control and floristic composition between palustrine and lacustrine wetlands were explored. We used a dataset of 168 vegetation plots (relevés), sampled at 45 mountain wetlands in the northern Apennines (central Italy). Direct ordination showed that water depth, geology type and altitude were the main factors responsible for species distribution. The most important gradient was linked to soil moisture, with hygrophilous species increasing with moisture levels. Indicator Species Analysis underlined a clear distinction in the distribution of aquatic plants between wetland subsystems. Geology and rainfall affected species assemblages in lacustrine and palustrine subsystems. Indirect ordination and Generalized Additive Models revealed that plant species and their attributes significantly changed in the wetland subsystems with an increase in hydrophytes with increasing rainfall in palustrine wetlands and a decrease in thermophilous species along an altitudinal gradient in lacustrine wetlands. Management and conservation guidelines for northern Apennines wetlands are suggested.
\end{abstract}

Keywords: aquatic biodiversity / lakes / marshes / ponds / vegetation

Résumé - Facteurs environnementaux qui guident l'agrégation des plantes: existe-t-il des différences entre les zones de marais et de lacs? Une étude de cas du nord des Apennins. Les zones humides de montagne font partie des habitats les plus vulnérables du bassin méditerranéen. Nos questions sont les suivantes : i) Quels sont les principaux facteurs environnementaux qui déterminent la composition des espèces dans les zones humides de montagne? ii) Quelles sont les différences de contrôle environnemental entre les différents sous-systèmes de zones humides (palustres ou lacustres) ? Nous avons utilisé un ensemble de 168 relevés, échantillonnés dans 45 zones humides de montagne du nord des Apennins (centre de l'Italie). L'ordination directe montre que la profondeur de l'eau, le type de géologie et l'altitude sont les principaux facteurs responsables de la répartition des espèces. Le gradient le plus important est lié à l'humidité du sol, les espèces hygrophiles augmentent avec les niveaux d'humidité. L'analyse des espèces indicatrices montre une distinction claire dans la répartition des plantes aquatiques entre les zones humides. En revanche, les mêmes facteurs, la géologie et les précipitations, ont affecté les espèces dans les sous-systèmes lacustres et palustres. Les autres analyses statistiques ont révélé que les plantes et ses attributs

\footnotetext{
*Corresponding author: gianmaria.bonari@gmail.com
} 
changent dans les deux types de zones humides avec une augmentation des hydrophytes à l'augmentation des précipitations dans les zones palustres et une diminution des espèces thermophiles le long du gradient d'altitude dans celles lacustres. Des directives de gestion et de conservation pour les zones humides nord des Apennins sont fournies.

Mots-clés : biodiversité aquatique / étangs / lacs / marais / végétation

\section{Introduction}

Wetlands are a key component for the conservation of biodiversity. Set at the transitional zone between terrestrial and aquatic ecosystems, they offer unique hydrological and biological conditions and suitable habitats for many threatened plant and animal species. Prolonged anthropogenic pressure and natural succession made them the most threatened habitats worldwide (Dudgeon et al., 2006). Freshwater ecosystems are among the most threatened habitats in Europe (Janssen et al., 2016). As highlighted in the third report on the conservation status of habitats in Italy, a high percentage of wetlands have a poor conservation status (Zivkovic et al., 2017; Gigante et al., 2018), showing evident fragmentation, area reduction, impoverished flora and invasion by alien species. Recent studies highlighted that many wetland plant communities are missing from the Habitats Directive and other protection lists, despite the fact that they are extremely rare in the Mediterranean basin (Gigante et al., 2013; Benavent-González et al., 2014; Lastrucci et al., 2014; Angiolini et al., 2017). As a general trend, European wetlands decrease in size and frequency from north to south. In the Mediterranean basin, most wetlands are in mountain areas (Gerdol and Tomaselli, 1993). Unlike in the Alps, the Apennines are rather poor in wetlands; here, wetlands are often fragmented and floristically less characterized, due a progressive loss of hygrophilous boreal species along the north-south gradient. In particular, at relatively low altitudes (below 1000 ma.s.1.), many Apennine wetlands are partially or completely artificial (Gerdol and Tomaselli, 1993). Nevertheless, also artificial wetlands can be important for the conservation of plant diversity, especially in view of the worldwide degradation of natural aquatic ecosystems and the associated decline in species richness (Hrivnák et al., 2014). A number of studies have also emphasized the importance of small wetlands, such as ponds and pools for biodiversity (De Meester et al., 2005; Edvardsen and Økland, 2006; Novikmec et al., 2016). The significance of regional and local ecological drivers of biodiversity in these habitats has been highlighted as well (De Meester et al., 2005). Two major drivers of community structure in small wetlands are the hydro-period gradient and the availability of water (De Meester et al., 2005 and references therein; Bolpagni et al., 2018). These aspects may become critical under thermal and rainfall anomalies (Bolpagni et al., 2018 and references therein). The central Mediterranean and Italian peninsula are therefore particularly vulnerable to climate change (Casazza et al., 2014).

In this context, northern Apennine wetlands offer the possibility of studying relations between environmental factors and species composition in southern European mountains. Here, wetlands occur mainly at altitudes below $1500 \mathrm{~m}$ and their origin might be natural (e.g. streams, marshes, ponds), artificial (e.g. irrigation ponds, waterholes) and/or affected by grazing (e.g. trampled wet meadows). These wetland subsystems differ in relation to the border between aquatic and terrestrial systems (see Rolon and Maltchik, 2006; Rolon et al., 2008). They can be classified either as "lacustrine", i.e. wetlands with at least temporary open water, such as small lakes, watering places and ponds, or "palustrine", i.e. marshy areas without open water, such as marshes, swamps and wet meadows.

Our hypothesis is that there are significant differences in floristic composition and environmental control between different palustrine and lacustrine wetland subsystems. These differences are mainly driven by water availability. Based on this hypothesis, the main questions we aimed to answer were: - What are the main environmental factors driving species composition in northern Apennine wetlands?

- Is the floristic composition of palustrine and lacustrine wetlands different and determined by diverse environmental drivers?

\section{Materials and methods}

\subsection{Study area}

The study area is situated in the Apennine mountains between Tuscany and Emilia-Romagna (central Italy; Fig. 1) and includes 45 wetland sites. The wetlands range from artificial lakes to small ponds, pools, streams and (trampled) wet meadows. The presence of water is also variable, ranging from permanently flooded (lakes) to temporarily flooded habitats. The wetland sites are at altitudes of 535 to $1470 \mathrm{~m}$.

Detailed information on climate and geology was obtained from various local vegetation studies (Viciani et al., 2002, 2004, 2010; Lastrucci et al., 2005, 2006; Viciani and Gabellini, 2006). Climate is generally (sub-)montane, not distinctly oceanic or continental, with mesic temperatures and moderate to heavy rainfall (depending on altitude), with maximum between October and February and minimum between June and August. According to Pesaresi et al. (2017), the study area has a temperate oceanic bioclimate at higher altitudes and a variant temperate oceanic-sub-Mediterranean bioclimate at lower altitudes.

There are four main geological formations in the area (Carmignani et al., 2013). Most slopes on the Tyrrhenian side have two types of siliceous sandstone, one with low percentages of limestone and the other consisting of silty schists, marl and fine siliceous and calcareous sandstone. Some massifs, such as "La Verna" in the south-eastern Tuscan part of the study area, consist of solid "Alberese" limestone which crops out above a chaotic series of clayey rocks (known as 

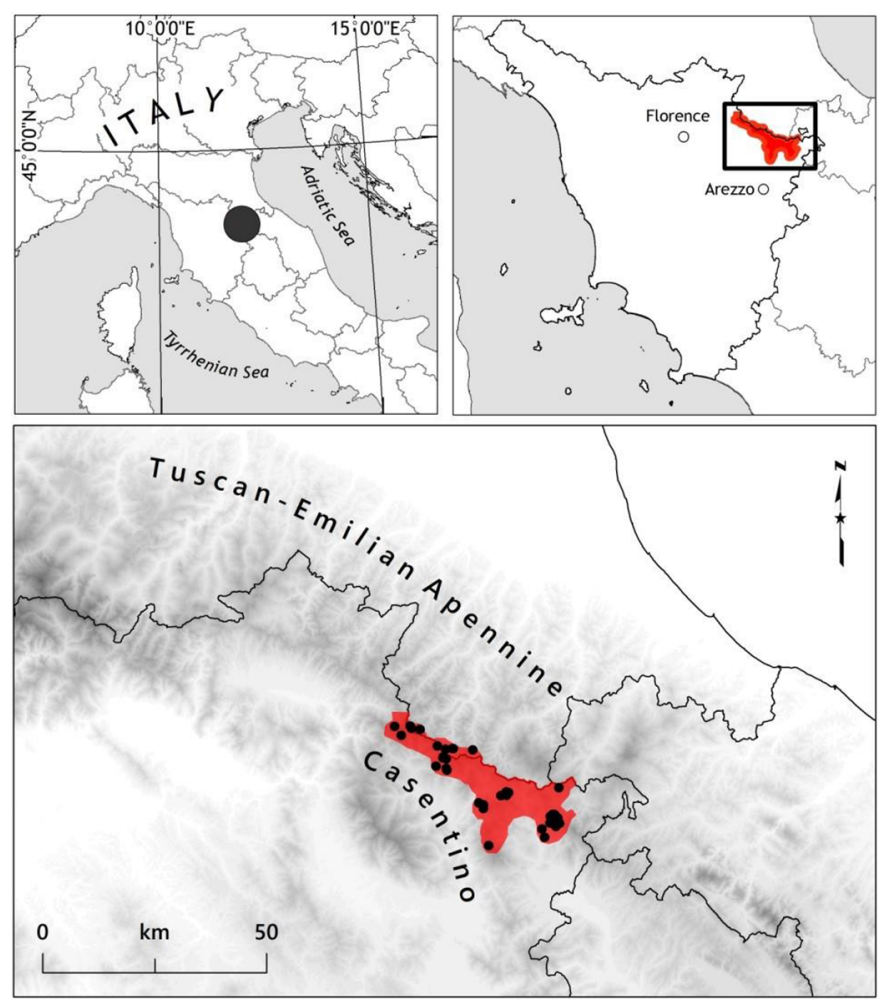

Fig. 1. Study area and its position in the northern Apennines and in Italy (boxes at the top right and left, respectively).

"Liguridi"). The slopes on the Adriatic side are more homogeneous with widespread sandstone-marly flysch formations consisting of sandstone, siltstone and marls with intercalations of calcareous clasts and marly limestone. In the study area other less extensive geological formations are also present (Carmignani et al., 2013).

\subsection{Vegetation and floristic data collection}

To investigate plant assemblages in the Apennine wetlands, 45 sites were sampled. Minimum, mean and maximum areas were $0.0006,0.11$ and 2.4 ha, respectively. The number of plots was proportional to the size of the sites (ranging from 2 to 18). A dataset of 168 relevés was obtained, including 126 lacustrine and 42 palustrine vegetation plots. The relevé area ranged from 1 (for small hydrophytes) to $50 \mathrm{~m}^{2}$ (for large helophytes), with plot sizes as standard as possible within same vegetation types. Plant species were recorded using the phytosociological method (Braun-Blanquet, 1932; Biondi, 2011). The percentage cover of each plant species (plant community composition) was estimated. The nomenclature of species is according to Conti et al. (2005) and the definition of families is according to Peruzzi (2010).

\subsection{Explanatory variables}

Two sets of variables were obtained, namely site and species attributes. They were measured in the field, calculated by GIS for each site or obtained from the literature.

\subsubsection{Site attributes}

The following site-related explanatory variables were used:

- wetland area (continuous) measured during survey activities with a tape measure and later checked by orthoimagery analysis in the GIS environment (QGIS, https:// www.qgis.org/it/site/);

- water depth (ordinal): the study sites were divided into three groups according to maximum depth measured in the field: i) $<10 \mathrm{~cm}$; ii) from $10 \mathrm{~cm}$ to $1 \mathrm{~m}$; iii) $>1 \mathrm{~m}$;

- water persistence (nominal): the study sites were divided into two groups: with permanent water throughout the year and those with a temporary lack of water in the dry season (summer);

- altitude (continuous) was measured in the field by GPS and later checked in a GIS environment;

- rainfall and temperature (continuous): for each sampling site, rainfall and temperature were calculated by data interpolation with GIS. Data were retrieved from available IBIMET-CNR sources for Tuscany and from Antolini et al. (2015) for Emilia-Romagna (https://www.arpae.it/detta glio_documento.asp?id=6147\&idlivello=1528);

- geology (nominal): the geological substrate of each site was assigned by overlap with the geological map of Italy retrieved from the Web Map Service of the National Geoportal (http://www.pcn.minambiente.it/). The following six geological types were identified: i) pelagic marls; ii) chaotic complex; iii) serpentinites; iv) sandstone/arenaceous marls; v) clay limestone; vi) skeletal limestone.

\subsubsection{Species attributes}

The following three species-related attributes, measured as the percentage presence of each category in the vegetation plots were extrapolated for each species:

- Raunkiær plant life forms were obtained from Pignatti (1982): i) chamaephytes; ii) geophytes, iii) hemicryptophytes; iv) hydrophytes; v) phanerophytes; vi) therophytes; - chorotypes were grouped by phytogeographical elements (for details see Viciani et al., 2016, modified): i) endemic; ii) boreal; iii) orophilous; iv) Eurasiatic; v) European; vi) S-European-Mediterranean; vii) wide distribution;

- inclusion in the conservation value lists (Conti et al., 1997; Regional Law 56/2000 and 30/2015; Castelli and Sposimo, 2005; Rossi et al., 2013).

\subsection{Data analysis}

To detect the main environmental factors driving central Apennine wetland species composition and dissimilarities between palustrine and lacustrine wetlands, different multivariate approaches were used. The characteristic species of the two wetland subsystems were explored by Indicator Species Analysis (INSPAN, Dufrène and Legendre, 1997) under the null hypothesis of no difference in species response across wetland types. To determine whether environmental factors significantly drive species assemblages in Apennine wetlands, constrained ordinations of the total dataset and of the two subsets (lacustrine wetlands, $n=126$; palustrine wetlands, 
$n=42)$ were used. Given the long data gradient $(>4$ SD in all datasets; Šmilauer and Lepš, 2014) measured with a preliminary Detrended Correspondence Analysis (DCA), we chose to apply a unimodal constrained ordination (Canonical Correspondence Analysis, CCA; ter Braak and Šmilauer, 2012). The most parsimonious model was fitted using a stepwise algorithm, adding the explanatory variables to the model by selecting the variables that best explained variations in the datasets, until the variables were no longer significant $(p>0.05)$. The relative importance of each explanatory variable was assessed.

To detect differences in the major environmental factor driving species composition in the two wetland subsystems, separate DCAs were performed to describe the general pattern of species distribution along gradients in palustrine and lacustrine wetlands (Lepš and Šmilauer, 2003). We also modelled changes in altitude and rainfall along the first DCA axes in relation to species, using a Generalized Additive Model (GAM) with quasi-Poisson distribution (ter Braak and Śmilauer, 2012). In the DCA diagrams, all species attributes were then projected passively, showing their variation across species data.

A randomized Monte Carlo test with 999 permutations was used to: i) evaluate the statistical significance of the maximum indicator value recorded for a given species (Dufrène and Legendre, 1997; McCune and Grace, 2002; Peck, 2004); ii) test the significance of the first and all constrained axes and of the effect of the variables on species composition in CCA. Spearman's non-parametric correlation coefficient was used to test relationships between ordination scores for sites and the distribution of species and environmental variables. The Bonferroni correction for multiple comparisons was applied to the CCA (ter Braak and Smilauer, 2012).

Prior to ordination analysis, Spearman's correlation coefficient was used to exclude strongly intercorrelated quantitative variables $(r>0.85)$; the "Wetland area" variable showing skewness $>1$ was $\log (x+1)$ transformed to reduce the effect of asymmetry and (natural) outliers, thus improving CCA performance (see McCune and Grace, 2002). Spearman's correlation coefficient was performed in R v.3.2.3 (R Core Team, 2017) while INSPAN was calculated using the software package PCORD 6.0 (McCune and Mefford, 2011). DCA and CCA were performed using CANOCO v. 5.04 (ter Braak and Šmilauer, 2012).

\section{Results}

In the vegetation plots of the 45 mountain wetlands, we found a total of 159 species, 108 genera and 46 families of vascular plants and two macroscopic algae (total: 161 taxa; see Appendix 1). The best represented families were Poaceae (21 taxa), Cyperaceae (15) and Asteraceae (12). Six pteridophytes were also recorded. The most abundant genera were Carex (11), Galium (5), Epilobium (4) and Veronica (4). The most frequent species in the vegetation plots were: Mentha aquatica subsp. aquatica, Ranunculus repens, Galium palustre subsp. palustre, Juncus inflexus, Veronica beccabunga and Rumex conglomeratus. Sixteen species were in regional or national red lists, and only two endemics, with distribution
Table 1. Indicator species for lacustrine and palustrine subsystems according to INSPAN.

\begin{tabular}{lccc}
\hline Species & Lacustrine & Palustrine & $p$-values \\
\hline Carex hirta & & $\times$ & 0.01 \\
Carex pendula & $\times$ & 0.05 \\
Dactylis glomerata & $\times$ & 0.05 \\
Epilobium hirsutum & $\times$ & 0.05 \\
Equisetum palustre & $\times$ & 0.05 \\
Geranium nodosum & & $\times$ & 0.05 \\
Holcus lanatus & $\times$ & 0.05 \\
Hypericum tetrapterum & $\times$ & 0.05 \\
Lemna minor & $\times$ & & 0.001 \\
Lycopus europaeus & & $\times$ & 0.05 \\
Mentha aquatica & $\times$ & 0.05 \\
Petasites hybridus & & $\times$ & 0.001 \\
Phragmites australis & $\times$ & & 0.01 \\
Poa trivialis & $\times$ & 0.05 \\
Potamogeton natans & $\times$ & & 0.01 \\
Pulicaria dysenterica & & $\times$ & 0.01 \\
Ranunculus tricophyllus & $\times$ & & 0.05 \\
Ranunculus lanuginosus & & $\times$ & 0.01 \\
Ranunculus repens & & $\times$ & 0.01 \\
Rumex obtusifolius & & $\times$ & 0.05 \\
Scrophularia umbrosa & & $\times$ & 0.01 \\
\hline
\end{tabular}

along the Apennine chain, were found (Arisarum proboscideum and Salix apennina). Schoenoplectus litoralis, a rare species linked to coastal and subcoastal wetlands, including brackish ones, was also recorded. On the other hand, only one alien species, with a very low frequency, was found (Veronica persica).

The best represented families remained the same when the flora of lacustrine (128 species) and palustrine (111 species) subsystems were considered separately. However, 21 species $(12.73 \%)$ showed a significant correlation with wetland subsystems, based on their indicator value (Tab. 1). Most species $(17 ; 10.6 \%$ of the total number) were associated with palustrine subsystem. They were mainly tall hygrophilous herbs typical of marsh edges, such as Epilobium hirsutum, Ranunculus repens and Petasites hybridus, together with species of wet meadows (i.e. Carex hirta, Equisetum palustre, Holcus lanatus). The aquatic species showed a distinct distribution pattern of wetland systems with Lemna minor, Potamogeton natans and Ranunculus trichophyllus, significantly associated with lacustrine subsystem.

\subsection{Drivers of plant species composition}

The CCA with plant species and explanatory factors along the first two axes (Fig. 2) explained a low but significant $(P<0.01)$ percentage of variance in species composition $(2.07 \%$ and $1.83 \%$, respectively). Only three significant explanatory variables (water depth, sandstone/arenaceous marls geological type, $P<0.01$; altitude, $P<0.05)$ were 


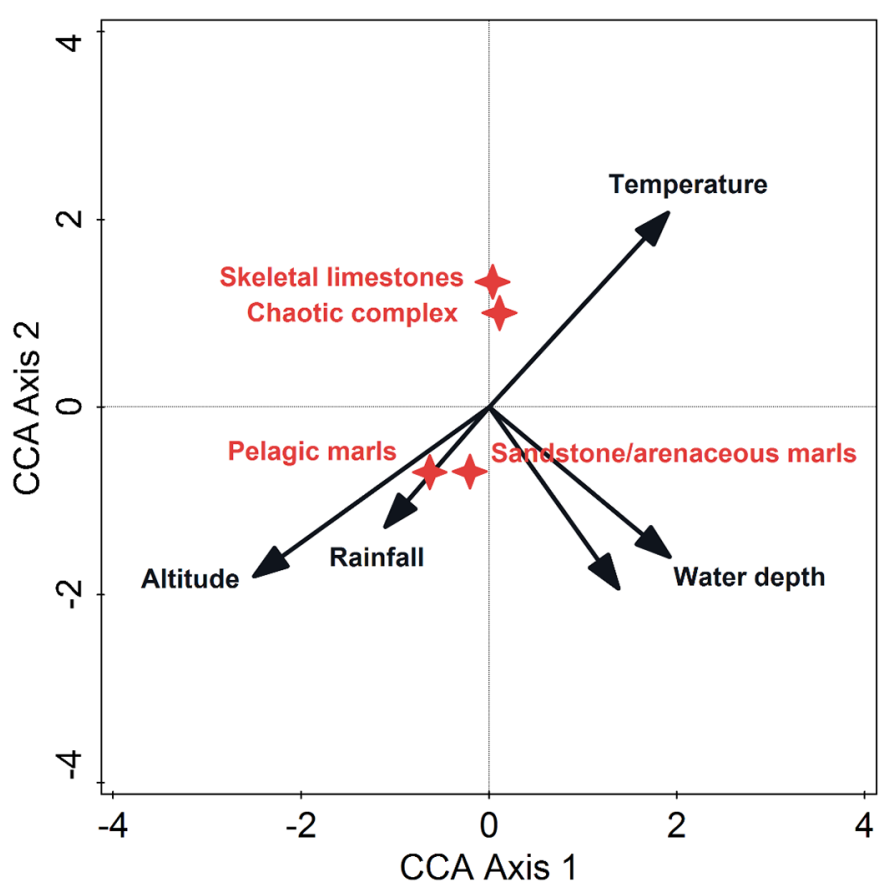

Fig. 2. CCA biplot of northern Apennine wetlands: significant environmental factors are indicated with arrows (continuous variables) and stars (nominal variables).

included in the CCA model and together explained $12.7 \%$ of the total variance. The first axis of the CCA diagram showed aquatic species (e.g. Potamogeton spp., Najas marina and algae of the genus Chara) in the positive part, helophytic/ amphibious species (e.g. Eleocharis palustris, Phragmites australis, Juncus spp.) in the centre, and those of wet meadows (e.g. Carex remota, Epilobium montanum, Milium effusum) in the negative part of the axis.

The CCAs performed separately for the two wetland subsystems revealed that a different number of factors controlled species composition of lacustrine and palustrine wetlands. Four significant explanatory factors were included in the CCA model for lacustrine wetlands: $11.3 \%$ of the species variance was explained by altitude $(\mathrm{F}=2.0, P<0.01)$, sandstone/arenaceous marls geological type $(\mathrm{F}=2.0, P$ $<0.01)$, rainfall $(\mathrm{F}=1.9, P<0.05)$ and clay limestone $(\mathrm{F}=1.6, P<0.05)$. The first and all canonical axes were significant $(\mathrm{F}=2.8, P<0.05$ and $\mathrm{F}=1.5, P<0.001$, respectively). For palustrine wetlands, only two significant explanatory factors were included in the CCA model, explaining 19\% of the variance in species composition (sandstone/arenaceous marls geological type, $\mathrm{F}=2.1, P<0.05$, and rainfall, $\mathrm{F}=2.0$, $P<0.05)$. The first and all canonical axes were significant (F=2.1, $P<0.1$ and $\mathrm{F}=1.2, P<0.05$, respectively).

\subsection{Plant species assemblages in the two subsystems related to altitude and climatic variables}

Using indirect ordination (DCA) of species data (biplot not shown), the first two axes explained $12.28 \%$ (lacustrine wetlands) and $16.95 \%$ (palustrine wetlands) of total species inertia. According to $\mathrm{CCA}$, the main gradient of floristic change linked to water depth was observed on both wetland subsystems, although it was more evident in lacustrine wetlands. The first axis in the lacustrine subsystem was also significantly linked to altitude. Climatic variables proved to be drivers of the gradient linked to the second axes (Tab. 2), being highly correlated with temperature in lacustrine $(P<0.01)$ and with rainfall in palustrine wetlands $(P<0.001)$; in the latter, the second axis also showed a correlation with altitude and temperature $(P<0.05)$. The other correlations between the wetland subsystems and the explanatory variables are summarized in Table 2.

Changes in rainfall and altitude along the first DCA axes were expressed as plot attributes based on GAMs, with plant life forms, chorotypes and important species passively projected (Figs. 3 and 4). The effects of rainfall on floristic variation were evident in both wetland subsystems. The percentages of hydrophytes increased at the highest rainfall values and species such as Potamogeton spp., Lemna minor, Ranunculus trichophyllus for lacustrine and Potentilla reptans, Ranunculus lanuginosus and Galium palustre for palustrine mainly occurred in the rainiest areas (Fig. 3). A similar trend for hydrophytes along the rainfall gradient was shown by species belonging to the wide distribution chorotype, prevalently represented in our data by aquatic plants. However, the trend of life forms and chorotypes along the rainfall gradient was more evident in the palustrine wetlands (Fig. 3B), with therophytes and species with European or S-European distribution clearly linked to the less rainy areas.

The distribution of wetland species and their attributes were affected by the altitude gradient, with therophytes, S-European Mediterranean and European chorotypes linked to lower altitudes and boreal or Eurasiatic species to the higher altitudes in both wetland subsystems. Lacustrine areas showed hydrophytes distributed at low altitudes and geophytes (such as Juncus effusus and J. inflexus) at high altitudes (Fig. 4A), while in palustrine wetlands the distribution trend of these life forms was the opposite (Fig. 4B).

\section{Discussion}

Our study demonstrated that northern Apennine wetlands are an important biodiversity reservoir shaped by a number of environments and related environmental features, such as water depth, wetland type, altitude and substrate.

Based on the number of species found (163), which were concentrated in a very small area (the sum of the areas surveyed was one hectare) and representing almost $15 \%$ of the flora of the National Park of the Casentino Forests, Monte Falterona and Campigna (Viciani et al., 2010), our results confirmed that mountain wetlands can host a relatively rich flora, including plants of high conservation value, as already reported for the Apennines by various authors (Gerdol and Tomaselli, 1987, 1993; Lastrucci et al., 2005, 2006; Foggi et al., 2011; Buldrini et al., 2017). Our findings are of particular importance considering the decline in species richness in natural aquatic ecosystems (Hrivnák et al., 2014) and in the wetlands of the Apennine chain (Gerdol and Tomaselli, 1993). Moreover, artificial mountain aquatic 
Table 2. Correlations between DCA axes 1 and 2 and environmental factors.

\begin{tabular}{lllll}
\hline Explanatory variables & Axis 1 Palustrine & Axis 2 Palustrine & Axis 1 Lacustrine & Axis 2 Lacustrine \\
\hline Environmental physical parameters & & & & \\
Wetland cover & $0.35^{*}$ & $0.36^{*}$ & n.s. & n.s. \\
Permanent wetland & n.s. & n.s. & n.s. & n.s. \\
Water depth & $0.33^{*}$ & n.s. & $-0.22^{*}$ & $0.31^{*}$ \\
Wetland area & n.s. & n.s. & n.s. & n.s. \\
Altitude & n.s. & $0.39^{*}$ & $0.25^{*}$ & n.s. \\
Rainfall & n.s. & $0.59^{* * *}$ & n.s. & n.s. \\
Temperature & n.s. & $-0.35^{*}$ & n.s. & $0.29^{*}$ \\
Geological types & & & & \\
Chaotic complex & n.s. & $-0.35^{*}$ & n.s. & n.s. \\
Clay limestone & n.s. & n.s. & n.s. & n.s. \\
Pelagic marls & - & - & n.s. & n.s. \\
Sandstone/arenaceous marls & n.s. & $0.40^{* * *}$ & n.s. & n.s. \\
Serpentinites & - & - & n.s. & \\
Skeletal limestone & - & - & n.s. \\
\hline
\end{tabular}

Superscripts indicate the $P$ values of the permutation test. n.s. $>0.05 ; *: \leq 0.05 ; * * *:<0.001$.

habitats may act as refugia for species of conservation importance. We found that more than $10 \%$ of the species recorded are included in Italian regional or national red lists. For instance, Carex pseudocyperus, Caltha palustris and Epipactis palustris are threatened and therefore of high conservation value (see Conti et al., 1997; Tuscan Region, 2000; Castelli and Sposimo, 2005; Rossi et al., 2013; Viciani et al., 2018). The presence of only 1 alien species (Veronica persica) is of interest considering the vulnerability of wetlands to invasion (see Kercher and Zedler, 2004) and the strong link between the non-native flora and European wetlands (Chytrý et al., 2008a; Pyšek et al., 2010; Angiolini et al., 2017). However, alien species tend to occur in low altitude wetlands (below $500 \mathrm{~m}$ a.s.1.) where human pressure is more intense and anthropogenic habitats prevail (Angiolini et al., 2013; Bolpagni et al., 2018). At higher altitudes, the reduction in number and size of anthropogenic habitats, along with low connectivity between neighboring sites, presumably restricts the spread of invasive plants due to the remoteness of these wetlands from alien sources (Becker et al., 2005; Chytrý et al., 2008b).

\subsection{Main environmental factors driving species composition}

The key factors shaping the distribution of plant species in mountain wetlands of the northern Apennines were primarily water depth and sandstone/arenaceous marls geological type, and secondarily altitude. As found by other authors (Dwire et al., 2006; Hammersmark et al., 2009), in wet ecosystems, water depth drives the distribution of Apennine mountain wetland flora, also influencing aquatic and helophyte species and determining a specific plant assemblage (see Weiher and Keddy, 1995). Water level fluctuations can cause distinct patterns among those plant communities that are mainly arranged according to a depth gradient (Van Eck et al., 2004; Azzella et al., 2013). The key role of sandstone/arenaceous marls geological type in shaping wetland species distribution, and the significant correlation of other geological types with CCA axes, highlights that bedrocks contribute to a great diversity of physical environments. It has been recognized as a primary regional determinant of wetland plant communities (e.g. Lougheed et al., 2001; Bubíková and Hrivnák, 2018). The sandstone/arenaceous marls geological type is mainly composed of arenaceous and pelitic-arenaceous lithofacies, and its low permeability, defined by the succession of sandstones and marls, limits the percolation of rainwater, creating superficial runoff (Galassi et al., 2011). This is in line with our finding because this geological type is positively correlated with factors linked to the relative availability of water (wetland cover, water depth and wetland area). Alterations in substrate composition, especially fine sediment, clearly have a direct effect on plant species composition in the studied wetlands. Considering the wide distribution of aquatic plants compared with those of terrestrial ecosystems, and since wetland vegetation is azonal, altitude has been considered a non-typical driver of floristic composition in mountain wetlands (Santamaría, 2002; Chambers et al., 2008). However, altitude necessarily includes other gradients (climatic, water quality and availability, human disturbance, vegetation heterogeneity) that influence aquatic and helophytic plants (Naqinezhad et al., 2009; Short et al., 2016; Bolpagni et al., 2018). This in turn may indirectly affect the distribution of wetland plant species (see Kamrani et al., 2011). Our results showed that species diversity increases with environmental heterogeneity. Therefore, to maintain wetland plant biodiversity, one of the best conservation strategies is to maintain habitat diversity (see also Lastrucci et al., 2015).

\subsection{Floristic composition and environmental factors in palustrine versus lacustrine wetlands}

A sharp effect of lacustrine and palustrine subsystems on floristic assemblages was found, especially in relation to the different (low versus high) influence of the terrestrial 

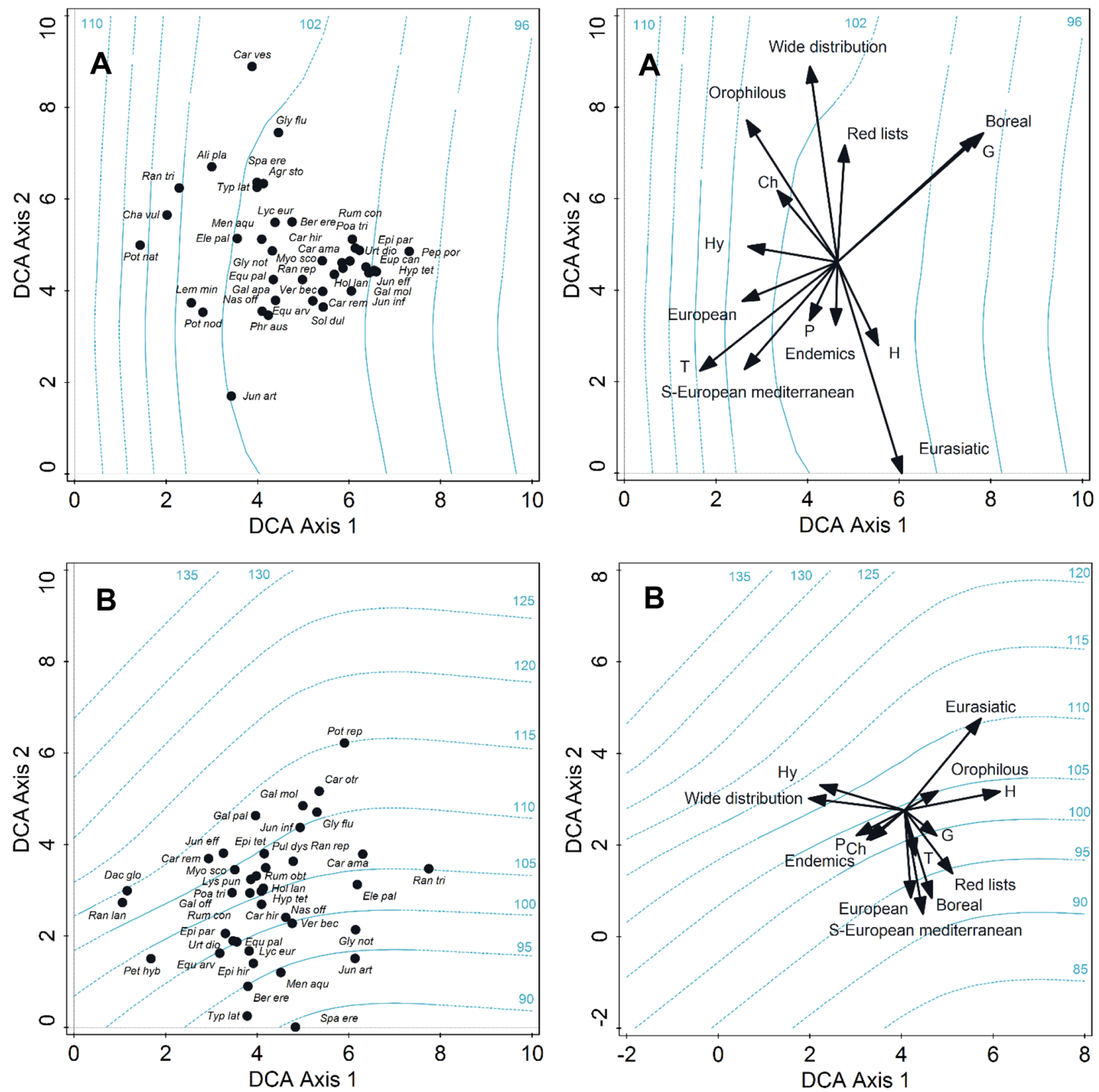

Fig. 3. DCA ordination biplots of northern Apennine wetland sites (A - lacustrine; B - palustrine). Change in rainfall (mm) along the first two DCA axes is expressed as an attribute plot based on the GAMs (in blue in the online version of the paper). Ch=chamaephytes; $\mathrm{G}=$ geophytes; $\mathrm{H}=$ hemicryptophytes; Hy=hydrophytes; $\mathrm{P}=$ phanerophytes; $\mathrm{T}=$ therophytes. For species name abbreviations see Appendix 1.

ecosystem (Rolon et al., 2008). This was underlined by the INSPAN results. There was a clear distinction in the distribution of aquatic plants between wetland subsystems. Three hydrophytes with a wide distribution in Italy (Bolpagni et al., 2018), were found to be exclusive to the lacustrine habitat, due to the presence of clearings and because they are obligate aquatic plants that do not tolerate long periods of drought. Phragmites australis is also linked to lacustrine wetlands, mainly forming aquatic reed beds consisting of one or few species. Among nonobligate aquatic species, hygrophilous tall herbs of fringes such as Epilobium hirsutum, Ranunculus repens and Petasites hybridus, species of wet meadows such as Carex hirta, Equisetum palustre and Holcus lanatus and herbaceous species not linked to water (i.e. Geranium nodosum and Dactylis glomerata), were related to the palustrine wetland subsystem. The higher species distinctiveness of the palustrine habitat is linked to the richness of hygrophilous species having their ecological optimum in marshes, swamps and wet meadows rather than in habitats characterized by the permanent presence of water. 

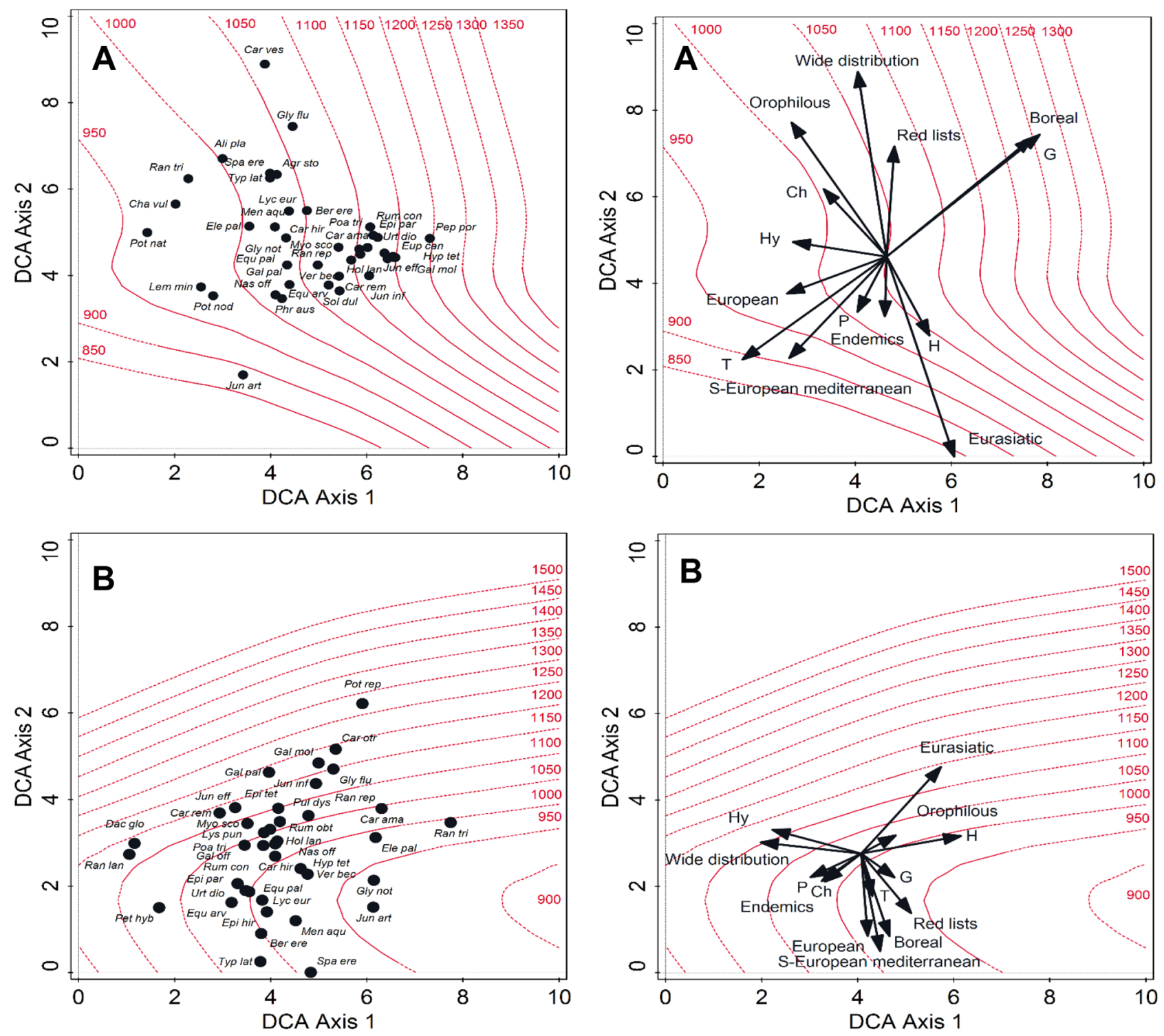

Fig. 4. DCA ordination biplots of northern Apennine wetland sites (A-lacustrine; B-palustrine). Change in altitude (m) along the first two DCA axes is expressed as an attribute plot based on the GAMs (in red in the online version of the paper). Ch= chamaephytes; $\mathrm{G}=\mathrm{geophytes}$; $\mathrm{H}=$ hemicryptophytes; $\mathrm{Hy}=$ hydrophytes; $\mathrm{P}=$ phanerophytes; $\mathrm{T}=$ therophytes. For species name abbreviations see Appendix 1 .

On the other hand, a clear distinction between key factors determining species assemblages in lacustrine and palustrine wetlands was not found. Both rainfall and geology led the distribution patterns of species, life forms and chorological forms. In both subsystems, the distribution of hydrophytes (Chara vulgaris, Ranunculus trichophyllus, Potamogeton natans) and/or hygrophilous species (such as Juncus spp. and Galium palustre) was linked to the highest rainfall values. However, the role of rainfall was fundamental in palustrine subsystems where the main spread of species, life forms and chorotypes was clearly visible along the increasing rainfall gradient, with therophytes and European chorotype distribution clearly linked to less rainy areas. In palustrine wetlands prevalently fed by rainwater, water availability varied greatly over time in relation to rainfall. Particularly in this subsystem, the scarcity of rainfall can be a limiting factor for the development and permanence of hygrophilous vegetation. At the same time, the role of geology is important in terms of soil wetness (moist versus dry soils), changing plant species composition that can grow in an area, but also in terms of morphology since it influences landforms (Nucci et al., 2012a) and consequently wetland types (open water systems versus marshes). Moreover, the ordinations highlighted a main gradient of water depth/soil moisture in the two subsystems, with hygrophilous species increasing with higher moisture levels. This gradient was more evident in the lacustrine wetlands. Another major factor driving the species distribution and the succession of plant communities in northern Apennine lacustrine and palustrine wetlands is soil moisture (Bolpagni et al., 2018). In the Apennine wetlands moisture is mainly 
linked to rainfall, substrate type and maintenance of traditional agro-pastoral activities, which are fundamental for the preservation of the species pools and for nature conservation in general (Gourmelon et al., 2001). The disappearance of traditional management activities has led to a change in floristic composition and community types. Therefore, conservation management should imitate the management that contributed historically to the development of currently preserved diversity as shown for different vegetation types (Bonari et al., 2017). In particular, wet meadows tend to evolve into mesophilous grasslands with the disappearance of many wetlands and their associated rare species (Middleton et al., 2006; Middleton, 2013).

In the northern Apennines the altitude drives species assemblages only in the lacustrine subsystem, where aquatic species seemed to occur prevalently at lower altitude. Deeper water bodies generally occur at lower altitudes due to the morphological characteristics of the Apennines. The few helophytes and hydrophytes found at higher altitudes may be explained by steep slopes and a lack of lakes, while the wettest areas are often the most low-lying and gently sloped (Bubíková and Hrivnák, 2018). However, plant species and their attributes changed significantly along the altitudinal gradient in both wetland subsystems, following an expected trend of species turnover: therophytes and Mediterranean and European chorotypes were more common at lower altitudes, whereas boreal or Eurasiatic species at higher altitudes, in relation to different temperature and drought values (Angiolini et al., 2011; Nucci et al., 2012b).

\section{Conclusion}

Based on our study of northern Apennine wetlands, the role of environmental variables such as water depth and substrate, is pivotal. These factors proved to be the best drivers of plant species distribution. Altitude was also found to influence species distribution. These findings are sustained by Apennine environmental heterogeneity, which hosts a variety of habitat types at different altitudes, along with heterogeneous substrates, climate factors and water levels.

The two wetland subsystems with their different species composition showed the same environmental drivers (rainfall and geology) determining plant species distribution. Our results also indicate that biological and chorological forms, especially hydrophytes and hygrophilous species, reflect the influence of rainfall and altitudinal gradients, highlighting the vulnerability of mountain wetland flora in a climate change perspective. Considered among the most vulnerable habitats, Apennine wetlands are threatened by climate change since potential shifts in distribution across mountain landscapes could have substantial consequences for wetland species, wetland ecosystems and their biological networks. Since drastic changes in precipitation patterns and temperatures are expected in the near future in Italy, our findings can be useful in this scenario.

We offer a series of proposals for developing conservation guidelines, which can have important applications for the conservation and management of aquatic and wet habitats in northern Apennines. Management efforts aimed at preserving species assemblages of Apennine wetlands should not only focus on local conditions of each lake or wet meadows, but also of their watersheds. In addition, the protection of a specific wetland area is not an appropriate strategy for the conservation of its plant species assemblages. In order to effectively conserve the plant species assemblages of the mountain wetland systems of central Italy, protocols should include areas with different range of altitudes, since wetlands at different altitudes and with different climate factors are distinct. Different geology and hydrological characteristics, providing heterogeneous conditions for aquatic and hygrophilous species, should be favoured as well.

Finally, our results suggest that palustrine wetlands are more heavily affected than lacustrine ones by water availability and persistence, as well as by climatic factors. In this respect, substrate alterations related to the use of heavy vehicles in forest management interventions should be avoided because they might cause change to the (micro-)topography and therefore modification of species assemblages. Under restricted resources, attention should be preferentially given to palustrine subsystem in order to minimize the probable loss of hygrophilous plants.

\section{Supplementary Material}

Appendix 1. Environmental drivers of plant assemblages: are there differences between palustrine and lacustrine wetlands?

The Supplementary Material is available at https://www.kmaejournal.org/10.1051/kmae/2019026/olm.

\section{References}

Angiolini C, Nucci A, Frignani, F, Landi M. 2011. Using multivariate analyses to assess effects of fluvial on plant species distribution in a Mediterranean river. Wetlands 31: 167-177.

Angiolini C, Nucci A, Landi M, Bacchetta G. 2013. Distribution of endemic and alien plants along Mediterranean rivers: A useful tool to identify areas in need of protection? $C R$ Biol 336: 416-423.

Angiolini C, Viciani D, Bonari G, Lastrucci L. 2017. Habitat conservation prioritization: A floristic approach applied to a Mediterranean wetland network. Plant Biosyst 151: 598-612.

Antolini G, Auteri L, Pavan V, Tomei F, Tomozeiu R, Marletto V. 2015. A daily high-resolution gridded climatic data set for Emilia-Romagna, Italy, during 1961-2010. Int J Climatol 36: 1970-1986.

Azzella MM, Rosati L, Blasi C. 2013. Phytosociological survey as a baseline for environmental status assessment: the case of hydrophytic vegetation of a deep volcanic lake. Plant Sociol 50: 33-46.

Becker T, Dietz H, Billeter R, Buschmann H, Edwards PJ. 2005. Altitudinal distribution of alien plant species in the Swiss Alps. PPEES 7: 173-183.

Benavent-González A, Lumbreras A, Molina JA. 2014. Plant communities as a tool for setting priorities in biodiversity conservation: A novel approach to Iberian aquatic vegetation. Biodivers Conserv 23: 2135-2154.

Biondi E. 2011. Phytosociology today: Methodological and conceptual evolution. Plant Biosyst 145: 19-29.

Bolpagni R, Laini A, Stanzani C, Chiarucci A. 2018. Aquatic plant diversity in Italy: Distribution, drivers and strategic conservation actions. Front Plant Sci. DOI: 10.3389/fpls.2018.00116. 
Bonari G, Fajmon $\mathrm{K}$, Malenovský $\mathrm{I}$, Zelený $\mathrm{D}$, Holuša $\mathrm{J}$, Jongepierová I, Kočárek $\mathrm{P}$, Konvička $\mathrm{O}$, Uřičáŕ J, Chytrý M. 2017. Management for both plant and insect diversity in seminatural grasslands: Heterogeneity and tradition are crucial. Agric Ecosyst Environ 246: 243-252.

Braun-Blanquet J. 1932. Plant sociology: The study of plant communities. New York: McGraw-Hill.

Bubíková K, Hrivnák R. 2018. Artificial ponds in Central Europe do not fall behind the natural ponds in terms of macrophyte diversity. Knowl Manag Aquat Ecosyst 419: 8.

Buldrini F, Pitoia F, Scabellone A, Cavalletti D, Chiarucci A, Pezzi G. 2017. Le aree umide del Parco Nazionale delle Foreste Casentinesi: Alcune considerazioni su flora e habitat. Quad Soc Studi Nat Romagna 45: 1-20.

Carmignani L, Conti P, Cornamusini G, Pirro A. 2013. Geological map of Tuscany (Italy). J Maps 9: 487-497.

Casazza G, Giordani P, Benesperi R, Foggi B, Viciani D, Filigheddu R, Farris E, Bagella S, Pisanu S, Mariotti MG. 2014. Climate change hastens the urgency of conservation for range-restricted plant species in the central-northern Mediterranean region. Biol Conserv 179: 129-138.

Castelli C, Sposimo P. 2005. L'archivio del repertorio naturalistico toscano. RENATO. Rassegna delle conoscenze sullo stato della biodiversità in Toscana. Attached CD-Rom. In Sposimo P, Castelli C, eds.La biodiversità in Toscana: specie e habitat in pericolo. Archivio del Repertorio Naturalistico Toscano. Regione Toscana, Direzione Generale Politiche Territoriali e Ambientali. Il Bandino, pp. $302+$ CD-Rom, Firenze.

Chambers PA, Lacoul P, Murphy KJ, Thomaz SM. 2008. Global diversity of aquatic macrophytes in freshwater. Hydrobiologia 595: 9-26.

Chytrý M, Maskell LC, Pino J, Pyšek P, Vilà M, Font X, Smart SM. 2008a. Habitat invasions by alien plants: A quantitative comparison among Mediterranean, subcontinental and oceanic regions of Europe. J Appl Ecol 45: 448-458.

Chytrý M, Jarošík V, Pyšek P, Hájek O, Knollová I, Tichý L, Danihelka J. 2008b. Separating habitat invasibility by alien plants from the actual level of invasion. Ecology 89: 1541-1553.

Conti F, Manzi A, Pedrotti F. 1997. Liste Rosse Regionali delle Piante d'Italia. WWF, Associazione Italiana per il World Wildlife Fund, in collaboration with the Società Botanica Italiana, Camerino.

Conti F, Abbate G, Alessandrini A, Blasi C. 2005. An annotated checklist of the Italian vascular Flora. Roma: Palombi Editor.

De Meester L, Declerck S, Stoks R Louette G, Van de Meutter F, De Bie T, Michels E, Brendonck L. 2005. Ponds and pools as model systems in conservation biology, ecology and evolutionary biology. Aquat Conserv 15: 715-725.

Dudgeon D, Arthington AH, Gessner MO, Kawabata Z, Knowler DJ, Lévêque C, Naiman RJ, Prieur-Richard A-H, Soto D, Stiassny MLJ, Sullivan CA. 2006. Freshwater biodiversity: Importance, threats, status and conservation challenges. Biol Rev Camb Philos Soc 81: 163-182.

Dufrène M, Legendre P. 1997. Species assemblages and indicator species: The need for a flexible asymmetrical approach. Ecol Monogr 67: 345-366.

Dwire KA, Kauffman JB, Baham JE. 2006. Plant species distribution in relation to water-table depth and soil redox potential in montane riparian meadows. Wetlands 26: 131-46.

Edvardsen A, Økland RH. 2006. Variation in plant species composition in and adjacent to 64 ponds in SE Norwegian agricultural landscapes. Aquat Bot 85: 79-91.

Foggi B, Lastrucci L, Papini P, Vergari S, Gennai M, Gervasoni D, Viciani D, Ferretti G. 2011. Vegetation of the Verdiana
River valley in the northern Apennines, Italy. Lazaroa 32: 153-178.

Galassi DM, Fiasca B, Del Tosto D. 2011. Patterns of copepod diversity (Copepoda: Cyclopoida, Harpacticoida) in springs of central Italy: Implications for conservation issues. Crustaceana monographs, studies on freshwater Copepoda: A volume in honour of Bernard Dussart. Leiden: Brill NV, pp. 199-226.

Gerdol R, Tomaselli M. 1987. Mire vegetation in the Apuanian Alps (Italy). Folia Geobot Phytotax 22: 25-33.

Gerdol R, Tomaselli M. 1993. The vegetation of wetlands in the northern Apennines (Italy). Phytocoenologia 21: 421-469.

Gigante D, Acosta ATR, Agrillo E, Armiraglio S, Assini S, Attorre F, Bagella S, Buffa G, Casella L, Giancola C, Giusso Del Galdo GP, Marcenò C, Pezzi G, Prisco I, Venanzoni R, Viciani D. 2018. Habitat conservation in Italy: The state of the art in the light of the first European Red List of Terrestrial and Freshwater Habitats. Rend Lincei Sci Fis Nat 29: 251-265.

Gigante D, Landucci F, Venanzoni R. 2013. The reed die-back syndrome and its implications for floristic and vegetational traits of Phragmitetum australis. Plant Sociol 50: 3-16.

Gourmelon F, Bioret F, Le Berre I. 2001. Land-use changes and implications for management of a small protected island off the coast of Bretagne. J Coast Conserv 7: 41-48.

Hammersmark CT, Rains MC, Wickland AC, Mount JF. 2009. Vegetation and water-table relationships in a hydrologically restored riparian meadow. Wetlands 29: 785-797.

Hrivnák R, Kochjarová J, Otahel’ová H, Pal'ove-Balang P, Slezák M, Slezák P. 2014. Environmental drivers of macrophyte species richness in artificial and natural aquatic water bodies - Comparative approach from two central European regions. Ann Limnol-Int J Lim 50: 269-278.

Janssen JAM, Rodwell JS, Criado MG, Gubbay S, Arts GHP. 2016. European Red List of Habitats. European Union.

Kamrani A, Jalili A, Naqinezhad A, Atta, F, Maassoumi AA, Shaw SC. 2011. Relationships between environmental variables and vegetation across mountain wetland sites, N. Iran. Biologia 66: 76-87.

Kercher SM, Zedler JB. 2004. Flood tolerance in wetland angiosperms: A comparison of invasive and non invasive species. Aquat Bot 80: 89-102.

Lastrucci L, Gonnelli V, Foggi B. 2005. Flora e vegetazione di alcune aree umide dell'altopiano della "Pianca" nell'alta Val Marecchia (Provincia di Arezzo, Toscana). Inform Bot Ital 36: 429-442.

Lastrucci L, Foggi B, Gonnelli V, Gusmeroli E. 2006. La vegetazione delle aree umide dei substrati ultramafici dell'Alta Valtiberina (Arezzo, Italia centrale). Studia Botanica 24: 9-44.

Lastrucci L, Bonari G, Angiolini C, Casini F, Giallonardo T, Gigante D, Landi M, Landucci F, Venanzoni R, Viciani D. 2014. Vegetation of lakes Chiusi and Montepulciano (Siena, central Italy): Updated knowledge and new discoveries. Plant Sociol 51: 29-55.

Lastrucci L, Lazzaro L, Guidi T, Gonnelli V, Giordani P, Benesperi R. 2015. Different components of plant diversity suggest the protection of a large area for the conservation of a riparian ecosystem. Biologia 70: 1033-1041.

Lepš J, Šmilauer P. 2003. Multivariate analysis of ecological data using CANOCO. Cambridge: Cambridge University Press.

Lougheed VL, Crosbie B, Chow-Fraser P. 2001. Primary determinants of macrophyte community structure in 62 marshes across the Great Lakes basin: Latitude, land use, and water quality effects. Can J Fish Aquat Sci 58: 1603-1612. 
McCune B, Grace JB. 2002. Analysis of ecological communities. Oregon: MJM, Gleneden Beach.

McCune B, Mefford MJ. 2011. PC-ORD for Windows. Multivariate Analysis of Ecological Data V.6.0.

Middleton BA. 2013. Rediscovering traditional vegetation management in preserves: Trading experiences between cultures and continents. Biol Conserv 158: 271-279.

Middleton BA, Holsten B, van Diggelen R. 2006. Biodiversity management of fens and fen meadows by grazing, cutting and burning. Appl Veg Sci 9: 307-316.

Naqinezhad A, Jalili A, Attar F, Ghahreman A, Wheeler BD, Hodgson JG, Shaw SC, Maassoumi A. 2009. Floristic characteristics of the wetland sites on dry southern slopes of the Alborz Mts., N. Iran: The role of altitude in floristic composition. Flora 204: 254-269.

Novikmec M, Hamerlík L, Kočický D, Hrivnák R, Kochjarová J, Otahel'ová H, Pal'ove-Balang P, Svitok M. 2016. Ponds and their catchments: size relationships and influence of land use across multiple spatial scales. Hydrobiologia 774: 155-166.

Nucci A, Angiolini C, Landi M, Bacchetta G. 2012a. Influence of bedrock-alluvial transition on plant species distribution along a Mediterranean river corridor. Plant Biosyst 146: 564-575.

Nucci A, Angiolini C, Landi M, Bacchetta G. 2012b. Regional and local patterns of riparian flora: Comparison between insular and continental Mediterranean rivers. Ecoscience 19: 213-224.

Peck J. 2004. Using PC-Ord for Multivariate Data Analysis. Unpublished training course manual.

Peruzzi L. 2010. Checklist dei generi e delle famiglie della flora vascolare italiana. Inform Bot Ital 42: 151-170.

Pesaresi S, Biondi E, Casavecchia S. 2017. Bioclimates of Italy. $J$ Maps 13: 955-960.

Pignatti S. 1982. Flora d'Italia, Vol. 1-3. Bologna: Edagricole.

Pyšek P, Bacher S, Chytrý M, Jarošík V, Wild J, Celesti-Grapow L, Gassó N, Kenis M, Lambdon PW, Nentwig W, Pergl J, Roques A, Sádlo J, Solarz W, Vilà M, Hulme PE. 2010. Contrasting patterns in the invasions of European terrestrial and freshwater habitats by alien plants, insects and vertebrates. Global Ecol Biogeogr 19: 317-331.

R Core Team. 2017. R: A Language and Environment for Statistical Computing. Vienna, Austria: R Foundation for Statistical Computing. Available from http://www.R-project.org.

Rolon AS, Maltchik L. 2006. Environmental factors as predictors of aquatic macrophyte richness and composition in wetlands of southern Brazil. Hydrobiologia 556: 221-231.

Rolon AS, Lacerda T, Maltchik L, Guadagnin DL. 2008. Influence of area, habitat and water chemistry on richness and composition of macrophyte assemblages in southern Brazilian wetlands. J Veg Sci 19: 221-228.

Rossi G, Montagnani C, Gargano D, Peruzzi L, Abeli T, Ravera S, Cogoni A, Fenu G, Magrini S, Gennai M, Foggi B, Wagensommer RP, Venturella G, Blasi C, Raimondo FM, Orsenigo S, eds. 2013. Lista Rossa della Flora Italiana. 1. Policy Species e altre specie minacciate. Comitato Italiano IUCN e Ministero dell'Ambiente e della Tutela del Territorio e del Mare.

Santamaría L. 2002. Why are most aquatic plants widely distributed? Dispersal, clonal growth and small-scale heterogeneity in a stressful environment. Acta Oecol 23: 137-154.

Short FT, Kosten S, Morgan PA, Malone S, Moore GE. 2016. Impacts of climate change on submerged and emergent wetland plants. Aquat Bot 135: 3-17.

Šmilauer P, Lepš J. 2014. Multivariate analysis of ecological data using CANOCO 5. Cambridge: Cambridge University Press.

ter Braak CJF, Šmilauer P. 2012. Canoco reference manual and user's guide: Software for ordination, version5.0. Ithaca, USA: Microcomputer Power.

Tuscan Region 2000. Legge Regionale 6 aprile 2000, n. 56 Norme per la conservazione e la tutela degli habitat naturali e seminaturali, della flora e della fauna selvatiche. Regione Toscana.

Van Eck WHJM, Van de Steeg HM, Blom CWPM, De Kroon H. 2004. Is tolerance to summer flooding correlated with distribution patterns in river floodplains? A comparative study of 20 terrestrial grassland species. Oikos 107: 393-405.

Viciani D, Gabellini A. 2006. La vegetazione dell'Alpe di Catenaia (Arezzo, Toscana) ed $\mathrm{i}$ suoi aspetti di interesse botanicoconservazionistico. Webbia 61: 167-191.

Viciani D, Gabellini A, Gonnelli V, De Dominicis V. 2002. La vegetazione della Riserva Naturale Alpe della Luna (Arezzo, Toscana) ed i suoi aspetti di interesse botanico-conservazionistico. Webbia 57: 153-170.

Viciani D, Gabellini A, Gonnelli V, De Dominicis V. 2004. La vegetazione della Riserva Naturale Alta Valle del Tevere-Monte Nero (Arezzo, Toscana) ed i suoi aspetti di interesse botanicoconservazionistico. Atti Soc Tosc Sci Nat, Mem, Ser B 109: $11-25$.

Viciani D, Gonnelli V, Sirotti M, Agostini N. 2010. An annotated checklist of the vascular flora of the "Parco Nazionale delle Foreste Casentinesi, Monte Falterona e Campigna" (Northern Apennines Central Italy). Webbia 65: 3-131.

Viciani D, Gennai M, Lastrucci L, Gabellini A, Armiraglio S, Caccianiga M, Andreis C, Foggi B. 2016. The Quercus petraeadominated communities in Italy: floristic, coenological and chorological diversity in an European perspective. Plant Biosyst 150: 1376-1394.

Viciani D, Geri F, Agostini N, Gonnelli V, Lastrucci L. 2018. Role of a geodatabase to assess the distribution of plants of conservation interest in a large protected area: A case study for a major national park in Italy. Plant Biosyst 152: 631-641.

Weiher E, Keddy P. 1995. The assembly of experimental wetland plant communities. Oikos 73: 323-335.

Zivkovic L, Biondi E, Pesaresi S, Lasen C, Spampinato G, Angelini P. 2017. The third report on the conservation status of habitats (Directive 92/43/EEC) in Italy: Processes, methodologies, results and comments. Plant Sociol 54: 51-64.

Cite this article as: Angiolini C, Viciani D, Bonari G, Zoccola A, Bottacci A, Ciampelli P, Gonnelli V, Lastrucci L. 2019. Environmental drivers of plant assemblages: are there differences between palustrine and lacustrine wetlands? A case study from the northern Apennines (Italy). Knowl. Manag. Aquat. Ecosyst., 420, 34. 